\title{
Family Psychoeducation in Reducing the Occurrence of Depression in Elderly: A Systematic Review
}

\author{
Cece Indriani ${ }^{1}$, Yati Sri Hayati ${ }^{2}$, Titin Andri Wihastuti ${ }^{3}$ \\ ${ }^{1}$ Students of Nursing Master Program Specialization in Psychiatric, Faculty of Medicine, \\ University of Brawijaya, Malang, Indonesia \\ ${ }^{2,3}$ Faculty of Medicine, University of Brawijaya, Malang, Indonesia \\ Email: titin.aw@gmail.com
}

\begin{abstract}
Depression is a chronic prevalence and recurrence disturbance. Depression in the elderly characterized by sadness, low interested in doing activity, and inability to feel happiness. But most families ignore it because they think it is a common problem in the elderly. Family psychoeducation therapy is one of the elements of family mental health care programs by providing information, education through therapeutic communication to reduce the scale of depression in the elderly. This systematic review aimed to determine family psychoeducation in reducing the occurrence of depression in the elderly. This systematic review begins with a question in advance and specify the destination, then search for the exact keyword searching to identify the data required in accordance with the purpose of the method of "AND" and "OR". After getting data from the searching results from 2005 to 2019 using proquest international databases, PubMed, science direct, and then proceed with the selection of DOAJ PRISMA flow diagram and criticism JBI tool to obtain the relevant article 23 to be analyzed into a systematic review. Family psychoeducation can improve cognitive abilities because in therapy contains elements that can improve family knowledge about the disease, teach techniques that can help families to know the symptoms of deviant behavior, as well as increased support for the family members themselves. This therapy can also reduce the scale of depression in the elderly. Family psychoeducation therapy can improve cognitive and psychomotor abilities significantly. Thus it can be used to improve the elderly and families coping itself. This therapy is not only used for people with schizophrenia, but also the patient's psychosocial, including depression in the elderly.
\end{abstract}

Keyword: Family Psychoeducation, Depression, Elderly.

\section{A. INTRODUCTION}

The process of aging is a lifelong process, not only starting from a certain time but starting from the beginning of life. The high life expectancy contributes to the high elderly population in a country, and it has become a worldwide phenomenon. The United States experienced an increase in the elderly in 2000, as many as 35 million adults over the age of 65 years accounted for $12.4 \%$ of the total population. Between 2015 and 2050 is estimated proportion of the population aged over 60 years will double from $12 \%$ to $22 \%$. In addition to the United States and Iraq, Poland also experienced the same thing with an increasing number of senior citizens over $30 \%$. This increase is due 
to the increase in life expectancy. Thus the higher the morbidity or mortality (Ahmed et al., 2017; Nofak et al., 2018).

Data of WHO indicated that the elderly population in the Sounteasr Asia region is $8 \%$, or about 142 million people in 2010. The elderly population is expected to increase three times by 2050. And in Indonesia in 2020 estimated the number of elderly around 80 million inhabitants. The number of elderly citizens in Indonesia also increased. In 2010 the percentage of the elderly population amounted to $9.77 \%$ and is predicted to continue to increase to 11.34\% in 2020 (Aswanira, 2015).

According to the high morbidity number in elderly causing physical and psychological changes. In addition, psychosocial changes that occur in old age due to changes in cognition, conditions of disease, loss of social roles also affect self-concept and the elderly can be a stressor, so vulnerable to psychological problems are common. The high stressors and events of life are not fun to raise the possibility of the elderly experiencing anxiety, loneliness, until the stage of depression (Rodrigues et al., 2014).

Depression is one of chronic prevalence and recurrence disorder (relapse). It is estimated that the number of people with depression in 2020 is increasing and will occupy the second place of the disease in the world.In terms of pharmacotherapy while quite effective in reducing acute depression and preventing relapse, except that only a small portion can provide a solution of elderly depression. Thus, we need a joint effort approach to somatic and non-somatic to reduce depression and lighten the burden for patients and their families. Depression in the elderly characterized by sadness, low interested in doing activity, and inability to feel happiness that ultimately will impact the risk of suicide. Depression in the elderly often occurs due to psychological factors including the type of personality and interpersonal relationships that include social support. One of the latest therapeutic discoveries for patients with depression that family psychoeducation that have proven effective and cost-effective for the treatment of patients with schizophrenia or major depression within a relatively long period of time (Simodera et al., 2012; Katsuki et al., 2018; Wroblewska et al., 2019).

Family psychoeducation is one of the elements of family mental health care programs by providing information, education through therapeutic communication. In addition, psycho-education program is also an approach that is educational and pragmatic. Family psychoeducation is a method based on the clinical findings to train families and working with mental health professionals as part of a comprehensive clinical care is planned for family members. Family psychoeducation intervention therapy is a relatively simple and easy, effective and cost is cheap enough to be given to patients with depression, especially in the elderly. Recent results show its effectiveness for unipolar depression and major depressive disorder (Simodera et al., 2012; Joseph, 2006; Tursi et al., 2013). 
Another study that examines the family psychoeducation in psychosocial burden experienced by the family said that families who participate in the program this therapy has a significant increase in knowledge of the concern of the burden and mental health patients. Results of family psychoeducation does provide a very positive impact for families and patients themselves, namely as a geriatric mental health supplement and pshycoparmalogical and reduce the impact of recurrence for patients with depression. But the test results is still limited due to lack of mechanism trial design changes that occur in patients with depression (Timmerby et al., 2018). The purpose of this study is to determine how the influence of family psychoeducation in reducing symptoms of depression in the elderly.

\section{B. METHOD}

The arrangement this paper consists of several stages that define research questions in advance by the method of the Picos. Furthermore, collecting data for this literature review by the method of searching "AND and OR" for each keyword, then use the diagram include: identification, screening, selection, feasibility, as well as determining the criteria for inclusion and exclusion criteria. In the final stage, writing a review carried out by synthesizing the literature to obtain a systematic review.

\section{Research question}

Questions in writing this review is "how the family psychoeducation therapy in reducing the incidence of depression in the elderly?".

\section{Identification Relevant Journals According to Title/Abstract}

Identificarion of relevant journal is conducted by searching for journal articles that have been published in the years 2005-2019 in international journals available in several of data base as proquest, PubMed, science direct, and DOAJ through advanced searching system. Search is performed by using a few key words, namely: "influence", "family psychoeducation therapy", "family therapy", "depression", "elderly", "depression in the elderly" with a system of incorporation "and" or "or". The selected reference adapted to the inclusion and exclusion criteria.

\section{Skrining and Eligibility}

According to the results of searching obtained as many as 4,875 titles of articles in proquest, 2,438 titles in PubMed, 168 titles in science direct, and 88 titles in DOAJ. A list of articles that are relevant to the research questions were identified. Having screened through an abstract obtained 52 relevant articles about family psychoeducation therapy and depression in the elderly. Selection followed by selecting the relevant journals to family psychoeducation therapy, decent (eligible) and have 
similar study design. In this final phase is only obtained 23 journals appropriate inclusion criteria.

\section{Selection dan Election Document}

Selection and election documents shall be made with the PRISMA flow diagram, can be seen in Figure 1.

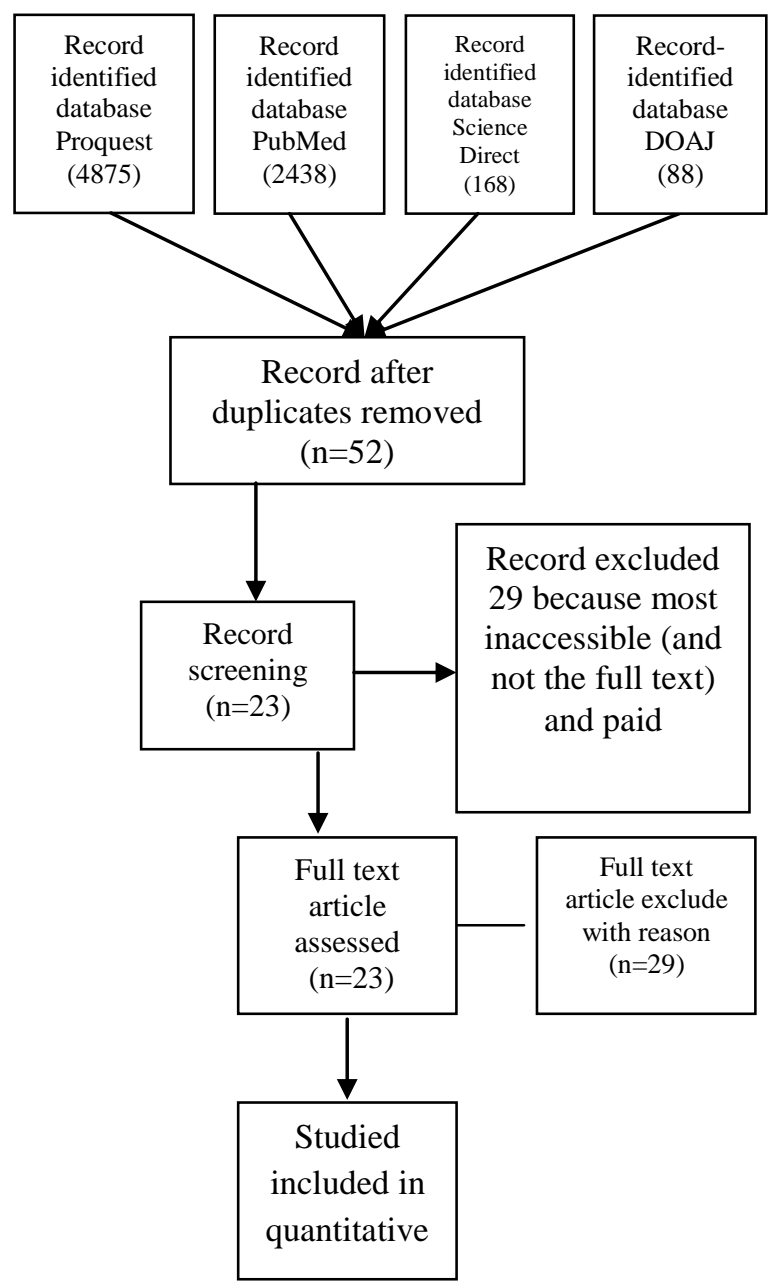

\section{Figure 1 PRISMA Diagram for Literature Identification}

\section{Appraisal}

There are twenty-three articles obtained and analyzed using instruments of journal critical of Joanna Brigg Institution (JBI) check list. Based on the appraisal obtained summary of the results listed in Table 1 and synthesized into a systematic review: 
Table 1 Summary of the Research Results on Family Psychoeducation Therapy

\begin{tabular}{|c|c|c|c|c|c|c|c|c|}
\hline $\begin{array}{c}\text { Authors } \\
\& \\
\text { year }\end{array}$ & Title & $\begin{array}{c}\text { JBI } \\
\text { level }\end{array}$ & Purpose & $\begin{array}{l}\text { Method } \\
\text { (Design) }\end{array}$ & Sample & $\begin{array}{c}\text { Interventio } \\
\mathbf{n}\end{array}$ & $\begin{array}{c}\text { Data } \\
\text { Analysis }\end{array}$ & $\begin{array}{l}\text { Major } \\
\text { Findings }\end{array}$ \\
\hline $\begin{array}{l}\text { Jennifer } \\
\text { Alvidres, } \\
\text { et al (2005) }\end{array}$ & $\begin{array}{l}\text { Psychoeduca } \\
\text { tion to } \\
\text { Increase } \\
\text { Psychothera } \\
\text { py Entry for } \\
\text { Older } \\
\text { African } \\
\text { Americans }\end{array}$ & 2.c & $\begin{array}{l}\text { Study to } \\
\text { determine } \\
\text { the effect of } \\
\text { psychoeduca } \\
\text { tion therapy } \\
\text { for the } \\
\text { elderly of } \\
\text { Africa- } \\
\text { American }\end{array}$ & $\begin{array}{l}\text { Experimen } \\
\text { tal test }\end{array}$ & $\begin{array}{l}\mathrm{N}=32 \\
\text { people } \\
\text { with } \\
\text { elderly } \\
\text { responde } \\
\text { nts }\end{array}$ & $\begin{array}{l}\text { Given the } \\
\text { therapy } \\
\text { consisting of } \\
\text { psychoeducat } \\
\text { ion sessions } \\
\text { beberapi }\end{array}$ & $\begin{array}{l}\text { No mention } \\
\text { is using } \\
\text { SPSS how } \\
\text { but using } \\
\text { PRISM-E } \\
\text { measuring } \\
\text { tool to } \\
\text { measure the } \\
\text { level of } \\
\text { depression } \\
\text { in elderly the } \\
\text { eld }\end{array}$ & $\begin{array}{l}\text { After being } \\
\text { given an } \\
\text { experimental } \\
\text { treatment } \\
\text { showed that } \\
\text { psychoeducatio } \\
\mathrm{n} \text { is very } \\
\text { significant and } \\
\text { the impact on } \\
\text { the elderly and } \\
\text { families } \\
\text { knowledge in } \\
\text { coping } \\
\text { problems } \\
\text { (depression) }\end{array}$ \\
\hline $\begin{array}{l}\text { Josef } \\
\text { Baumul, et } \\
\text { al } \\
(2006)\end{array}$ & $\begin{array}{l}\text { Psychoeduca } \\
\text { tion: A } \\
\text { Basic } \\
\text { psychothera } \\
\text { peutic } \\
\text { Intervention } \\
\text { for Patients } \\
\text { With } \\
\text { Schizophren } \\
\text { ia and Their } \\
\text { Families }\end{array}$ & 2.c & $\begin{array}{l}\text { To } \\
\text { determine } \\
\text { the } \\
\text { effectiveness } \\
\text { of family } \\
\text { psychoeduca } \\
\text { tion therapy } \\
\text { to prevent } \\
\text { relapse }\end{array}$ & $\begin{array}{l}\text { Using the } \\
\text { experiment } \\
\text { al } \\
\text { interventio } \\
\mathrm{n}\end{array}$ & - & $\begin{array}{l}\text { Explains that } \\
\text { the therapy } \\
\text { used quite a } \\
\text { lot, merging } \\
\text { BT, CBT, } \\
\text { psychoeducat } \\
\text { ion consisted } \\
\text { of } 4 \text { sessions }\end{array}$ & $\begin{array}{l}\text { Not } \\
\text { explained } \\
\text { analysis } \\
\text { used }\end{array}$ & $\begin{array}{l}\text { Psychoeducatio } \\
\mathrm{n} \text { is effectively } \\
\text { used for patients } \\
\text { with depression } \\
\text { and patients can } \\
\text { know with other } \\
\text { patients. }\end{array}$ \\
\hline $\begin{array}{l}\text { Kwok, } \\
\text { Sylvia et al } \\
(2011)\end{array}$ & $\begin{array}{l}\text { The } \\
\text { Moderating } \\
\text { Role of } \\
\text { Perceived } \\
\text { Social } \\
\text { Support on } \\
\text { the } \\
\text { Relationshi } \\
\text { p between } \\
\text { Physical } \\
\text { and } \\
\text { Functional } \\
\text { Impairment } \\
\text { Depressive } \\
\text { Symptoms } \\
\text { among } \\
\text { Chinese } \\
\text { Elderly } \\
\text { Nursing } \\
\text { Home in } \\
\text { Hong Kong }\end{array}$ & 4.b & $\begin{array}{l}\text { To test the } \\
\text { role of } \\
\text { support } \\
\text { perceived } \\
\text { social on the } \\
\text { relationship } \\
\text { between } \\
\text { physical } \\
\text { functional } \\
\text { impairment, } \\
\text { sources of } \\
\text { stress, and } \\
\text { depressive } \\
\text { symptoms } \\
\text { dip anti } \\
\text { decrepit } \\
\text { China } \\
\text { Hongkong }\end{array}$ & $\begin{array}{l}\text { The study } \\
\text { design } \\
\text { using a } \\
\text { cross } \\
\text { sectional } \\
\text { study and } \\
\text { survey } \\
\text { methods }\end{array}$ & $\mathrm{N}$ & $\begin{array}{l}\text { GDS } \\
\text { questionnaire } \\
\text { were } \\
\text { analyzed } \\
\text { through } \\
\text { statistical } \\
\text { analysis }\end{array}$ & $\begin{array}{l}\text { Using } \\
\text { Pearson } \\
\text { correlation } \\
\text { test and } \\
\text { regression } \\
\text { analysis }\end{array}$ & $\begin{array}{l}\text { The results } \\
\text { showed that } \\
\text { women show } \\
\text { symptoms of } \\
\text { depression } \\
\text { more than } \\
\text { elderly men, } \\
\text { and found a } \\
\text { positive } \\
\text { relationship } \\
\text { between } \\
\text { education level } \\
\text { and depressive } \\
\text { symptoms. }\end{array}$ \\
\hline $\begin{array}{l}\text { Shinji } \\
\text { Simodera, } \\
\text { et al } \\
(2012)\end{array}$ & $\begin{array}{l}\text { Cost- } \\
\text { effectiveness } \\
\text { of family } \\
\text { psychoeduca } \\
\text { tion to } \\
\text { Prevent } \\
\text { relapse in } \\
\text { major }\end{array}$ & $2 . d$ & $\begin{array}{l}\text { To identify } \\
\text { the } \\
\text { effectiveness } \\
\text { of } \\
\text { psychoeduca } \\
\text { tion in } \\
\text { patients with } \\
\text { unipolar }\end{array}$ & $\begin{array}{l}\text { Not } \\
\text { submitted } \\
\text { research } \\
\text { methods }\end{array}$ & 57 & $\begin{array}{l}\text { Using the } \\
\text { method of } \\
\text { TAU educate } \\
\text { families } \\
\text { consisting of } \\
4 \text { sessions }\end{array}$ & $\begin{array}{l}\text { Using } \text { SPSS } \\
\text { version } 20\end{array}$ & $\begin{array}{l}\text { The study states } \\
\text { that family } \\
\text { psychoeducatio } \\
\mathrm{n} \text { therapy is } \\
\text { very effective to } \\
\text { be used to } \\
\text { prevent the } \\
\text { recurrence of }\end{array}$ \\
\hline
\end{tabular}




\begin{tabular}{|c|c|c|c|c|c|c|c|c|}
\hline & $\begin{array}{l}\text { depression: } \\
\text { Results from } \\
\text { a } \\
\text { randomized } \\
\text { controlled } \\
\text { trial }\end{array}$ & & $\begin{array}{l}\text { depression } \\
\text { and costs } \\
\text { required to } \\
\text { perform } \\
\text { such therapy }\end{array}$ & & & & & $\begin{array}{l}\text { depressed } \\
\text { patients with a } \\
\text { relatively very } \\
\text { cheap }\end{array}$ \\
\hline $\begin{array}{l}\text { Tursi, MF, } \\
\text { et al } \\
(2013)\end{array}$ & $\begin{array}{l}\text { Effectivenes } \\
\text { s of } \\
\text { psychoeduca } \\
\text { tion for } \\
\text { depression }\end{array}$ & 2.A & $\begin{array}{l}\text { To evaluate } \\
\text { the } \\
\text { effectiveness } \\
\text { of therapy in } \\
\text { patients with } \\
\text { unipolar } \\
\text { depression } \\
\text { psychoeduca } \\
\text { tion }\end{array}$ & $\begin{array}{l}\text { Not } \\
\text { submitted } \\
\text { research } \\
\text { methods }\end{array}$ & & $\begin{array}{lr}\text { Using } & \text { the } \\
\text { GDS } & \text { scale } \\
\text { with } & 15 \\
\text { questions } & \end{array}$ & $\begin{array}{l}\text { Unspecified } \\
\text { analysis } \\
\text { used }\end{array}$ & $\begin{array}{l}\text { From the results } \\
\text { of the study } \\
\text { states that after } \\
\text { being evaluated, } \\
\text { psychoeducatio } \\
\mathrm{n} \text { is effective } \\
\text { against } \\
\text { depression } \\
\text { treatment }\end{array}$ \\
\hline $\begin{array}{l}\text { George } \\
\text { Rodrigues, } \\
\text { et all } \\
(2014)\end{array}$ & $\begin{array}{l}\text { A } \\
\text { psychoeduca } \\
\text { tional } \\
\text { support } \\
\text { group for } \\
\text { Latino older } \\
\text { adults } \\
\text { experiencing } \\
\text { symptoms of } \\
\text { Depression: } \\
\text { A grant } \\
\text { proposal }\end{array}$ & 2.d & $\begin{array}{l}\text { To prepare a } \\
\text { grant } \\
\text { proposal on } \\
\text { family } \\
\text { psychoeduca } \\
\text { tion in older } \\
\text { adults with } \\
\text { depressive } \\
\text { symptoms }\end{array}$ & $\begin{array}{l}\text { Pre and } \\
\text { post } \\
\text { interventio } \\
\mathrm{n} \text { (paired } \\
\text { sample } \mathrm{t}- \\
\text { test) }\end{array}$ & $\mathrm{N}=409$ & $\begin{array}{l}\text { Provide PTC } \\
\text { (powerful } \\
\text { tool for } \\
\text { caregivers) } \\
\text { Management } \\
\text { with } \\
\text { psychoeducat } \\
\text { ion-based } \\
\text { therapy }\end{array}$ & $\begin{array}{l}\text { Using } \text { SPSS } \\
\text { version } 22\end{array}$ & $\begin{array}{l}\text { Psycho- } \\
\text { education to } \\
\text { increase } \\
\text { knowledge of } \\
\text { caregivers in } \\
\text { making } \\
\text { treatment for } \\
\text { the elderly to } \\
\text { perform self- } \\
\text { care, self- } \\
\text { efficacy, } \\
\text { emotion } \\
\text { management } \\
\text { when symptoms } \\
\text { of depression } \\
\text { appear. }\end{array}$ \\
\hline $\begin{array}{l}\text { Aswanira, } \\
\text { et al (2015) }\end{array}$ & $\begin{array}{l}\text { The Effect of } \\
\text { Life Review } \\
\text { to the } \\
\text { Depression } \\
\text { in Elderly } \\
\text { People }\end{array}$ & $2 . d$ & $\begin{array}{l}\text { To see the } \\
\text { effect of } \\
\text { therapy in } \\
\text { the elderly } \\
\text { who suffer } \\
\text { from } \\
\text { depression } \\
\text { as well as } \\
\text { education in } \\
\text { the family }\end{array}$ & $\begin{array}{l}\text { Quantitativ } \\
\mathrm{e} \text { research } \\
\text { design of } \\
\text { pre } \\
\text { experiment } \\
\text { one group } \\
\text { pre-post } \\
\text { test }\end{array}$ & $\mathrm{N}=28$ & $\begin{array}{l}\text { This study } \\
\text { uses } \\
\text { extension }\end{array}$ & $\begin{array}{l}\text { Using GDS } \\
\text { intervention }\end{array}$ & $\begin{array}{l}\text { Life review } \\
\text { therapy and } \\
\text { psychoeducation } \\
\text { recommended } \\
\text { as an alternative } \\
\text { to nursing } \\
\text { actions soul for } \\
\text { depression in } \\
\text { the elderly and } \\
\text { families }\end{array}$ \\
\hline $\begin{array}{l}\text { Timmerby, } \\
\text { et al (2016) }\end{array}$ & $\begin{array}{l}\text { Family } \\
\text { psychoeduc } \\
\text { ation for } \\
\text { major } \\
\text { depressive } \\
\text { disorder - } \\
\text { study } \\
\text { protocol } \\
\text { for } \\
\text { randomized } \\
\text { controlled } \\
\text { trial }\end{array}$ & 1.c & $\begin{array}{l}\text { To } \\
\text { determine } \\
\text { the effect of } \\
\text { family } \\
\text { psychoeduc } \\
\text { ation } \\
\text { compared } \\
\text { to social } \\
\text { support in } \\
\text { the course } \\
\text { of the } \\
\text { disease in } \\
\text { patients } \\
\text { with } \\
\text { major } \\
\text { depressive } \\
\text { disorder. }\end{array}$ & $\begin{array}{l}\text { The study } \\
\text { design } \\
\text { using } \\
\text { dual- } \\
\text { center, } \\
\text { two- } \\
\text { armed, } \\
\text { observer- } \\
\text { blinded, } \\
\text { randomize } \\
\text { d } \\
\text { controlled } \\
\text { trial. }\end{array}$ & $\mathrm{N}=100$ & $\begin{array}{l}\text { Using family } \\
\text { psychoeducat } \\
\text { ion therapy } \\
\text { with } \quad 4 \\
\text { sessions and } \\
\text { social support } \\
4 \text { therapy } \\
\text { sessions led } \\
\text { by healthcare } \\
\text { workers }\end{array}$ & $\begin{array}{l}\text { Using } \\
\text { HAM-D } \\
\text { questionnair } \\
\text { e analysis by } \\
\text { dividing the } \\
\text { two phases } \\
\text { which } \\
\text { intervention } \\
\text { and follow- } \\
\text { up phase }\end{array}$ & $\begin{array}{l}\text { Results of this } \\
\text { research are } \\
\text { expected to } \\
\text { provide an } \\
\text { explanation FPE } \\
\text { change } \\
\text { mechanism and } \\
\text { social support } \\
\text { for the long- } \\
\text { term effects for } \\
\text { patients and } \\
\text { families of } \\
\text { patients }\end{array}$ \\
\hline
\end{tabular}




\begin{tabular}{|c|c|c|c|c|c|c|c|c|}
\hline $\begin{array}{l}\text { Panju } \\
\text { Pilania, et } \\
\text { al } \\
\text { (2017) }\end{array}$ & $\begin{array}{l}\text { Family } \\
\text { psychoeduca } \\
\text { tion for } \\
\text { Major } \\
\text { Depressive } \\
\text { Disorder }\end{array}$ & 4.b & $\begin{array}{l}\text { To identify } \\
\text { the } \\
\text { incidence of } \\
\text { depression } \\
\text { in the } \\
\text { elderly and } \\
\text { caregivers } \\
\text { spikoedukas } \\
\text { i }\end{array}$ & $\begin{array}{l}\text { Cross- } \\
\text { sectional } \\
\text { and use chi } \\
\text { square test } \\
\text { and the } \\
\text { logictic } \\
\text { multiple } \\
\text { regression, } \\
\text { odds ratios } \\
\text { and CI }\end{array}$ & $\begin{array}{l}\mathrm{N}=500 \\
\text { people } \\
\text { with } \\
\text { elderly } \\
\text { aged } 60 \\
\text { years }\end{array}$ & $\begin{array}{l}\text { Looking } \\
\text { levels of } \\
\text { depression } \\
\text { using GDS } \\
\text { format } \\
\text { (Geriatric } \\
\text { Depression } \\
\text { Scale) and } \\
\text { provide } \\
\text { education to } \\
\text { caregivers } \\
\text { (family) }\end{array}$ & $\begin{array}{l}\text { Using SPSS } \\
\text { version } 22\end{array}$ & $\begin{array}{l}\text { The study said } \\
\text { that the results } \\
\text { of research the } \\
\text { elderly aged } \\
\text { over } 50 \text { at } \\
\text { higher risk of } \\
\text { depression and } \\
\text { need education } \\
\text { exerts on the } \\
\text { family as a } \\
\text { caregiver }\end{array}$ \\
\hline $\begin{array}{l}\text { Sarifi } \\
\text { Mehdi, et } \\
\text { al (2017) }\end{array}$ & $\begin{array}{l}\text { Relationshi } \\
\text { p of } \\
\text { Determinist } \\
\text { ic Thinking } \\
\text { With } \\
\text { Loneliness } \\
\text { and } \\
\text { Depression } \\
\text { in the } \\
\text { Elderly }\end{array}$ & 2.c & $\begin{array}{l}\text { To } \\
\text { determine } \\
\text { the } \\
\text { relationship } \\
\text { between } \\
\text { deterministic } \\
\text { thinking and } \\
\text { depression, } \\
\text { and } \\
\text { loneliness in } \\
\text { the elderly }\end{array}$ & $\begin{array}{l}\text { Correlation } \\
\text { descriptive } \\
\text { using chi } \\
\text { square test } \\
\text { and the } \\
\text { multiple } \\
\text { regression } \\
\text { logictic } \\
\text { (AMOS) }\end{array}$ & $\begin{array}{l}142 \\
\text { elderly } \\
\text { aged over } \\
60 \text { years }\end{array}$ & $\begin{array}{l}\text { Looking } \\
\text { levels of } \\
\text { depression } \\
\text { using GDS } \\
\text { format } \\
\text { (Geriatric } \\
\text { Depression } \\
\text { Scale), to } \\
\text { measure the } \\
\text { deterministic } \\
\text { use Younesi } \\
\text { and Mirafzal }\end{array}$ & $\begin{array}{l}\text { Using } \\
\text { software } \\
\text { AMOS and } \\
\text { path } \\
\text { analysis }\end{array}$ & $\begin{array}{l}\text { The results of } \\
\text { the path } \\
\text { analysis model } \\
\text { showed that } \\
\text { thinking } \\
\text { determinsitic } \\
\text { have } \\
\text { significant and } \\
\text { positive } \\
\text { relationship to } \\
\text { depression (p } \\
0.001 \text { ) and } \\
\text { variables alone } \\
\text { (p 0.001), so } \\
\text { deterministic act } \\
\text { as a predictor } \\
\text { for the mental } \\
\text { health of elderly }\end{array}$ \\
\hline $\begin{array}{l}\text { Rhys } \\
\text { Jones, et al } \\
(2017)\end{array}$ & $\begin{array}{l}\text { Psychoeduc } \\
\text { ational } \\
\text { interventio } \\
\text { ns in } \\
\text { adolescent } \\
\text { depression: } \\
\text { A } \\
\text { systematic } \\
\text { review }\end{array}$ & 1.c & $\begin{array}{l}\text { To find out } \\
\text { prevention / } \\
\text { management } \\
\text { of } \\
\text { depression } \\
\text { in teens }\end{array}$ & $\begin{array}{l}\text { Through a } \\
\text { database } \\
\text { search } \\
\text { system } \\
\text { using } \\
\text { PubMed, } \\
\text { PsycINFO, } \\
\text { EMBASE, } \\
\text { guidelines, } \\
\text { and several } \\
\text { reviews } \\
\text { referral }\end{array}$ & 15 articles & using RCT & $\begin{array}{l}\text { Comparison } \\
\text { of } 15 \text { articles }\end{array}$ & $\begin{array}{l}\text { According to } 15 \\
\text { articles, was } \\
\text { found seven } \\
\text { teenagers who } \\
\text { diagnosed } \\
\text { depression and } \\
8 \text { youth at risk } \\
\text { of depression. } \\
\text { With the PI can } \\
\text { prevent and } \\
\text { manage } \\
\text { depression in } \\
\text { teens }\end{array}$ \\
\hline $\begin{array}{l}\text { Katsuki, et } \\
\text { al (2018) }\end{array}$ & $\begin{array}{l}\text { Brief } \\
\text { multifamily } \\
\text { psychoeduc } \\
\text { ation for } \\
\text { family } \\
\text { members of } \\
\text { Patients } \\
\text { with } \\
\text { chronic } \\
\text { major } \\
\text { depression: } \\
\text { a } \\
\text { randomized } \\
\text { controlled } \\
\text { trial } \\
\end{array}$ & 2.c & $\begin{array}{l}\text { To } \\
\text { investigate } \\
\text { the effect of } \\
\text { short } \\
\text { multifamily } \\
\text { psychoeduc } \\
\text { ation (BMP) } \\
\text { on the } \\
\text { mental } \\
\text { health } \\
\text { status of } \\
\text { family } \\
\text { members of } \\
\text { patients } \\
\text { with MDD } \\
\end{array}$ & $\begin{array}{l}\text { Desan } \\
\text { ekspreime } \\
\text { ntal study } \\
\text { with } \\
\text { control }\end{array}$ & $\mathrm{N}=49$ & $\begin{array}{l}\text { BMP } \\
\text { interventions } \\
\text { (psychoeduca } \\
\text { tion } \\
\text { multyfamily) } \\
\text { to the } \\
\text { intervention } \\
\text { and control } \\
\text { groups }\end{array}$ & $\begin{array}{l}\text { Using } \\
\text { intention to } \\
\text { threat } \\
\text { analysis }\end{array}$ & $\begin{array}{l}\text { Four sessions } \\
\text { BMP does not } \\
\text { significantly } \\
\text { reduce the } \\
\text { psychological } \\
\text { distress of } \\
\text { family members } \\
\text { of patients with } \\
\text { chronic MDD }\end{array}$ \\
\hline
\end{tabular}




\begin{tabular}{|c|c|c|c|c|c|c|c|c|}
\hline & & & chronic. & & & & & \\
\hline $\begin{array}{l}\text { Ibrahim } \\
\text { Ahmed, et } \\
\text { al (2019) }\end{array}$ & $\begin{array}{l}\text { Mental } \\
\text { Disorders } \\
\text { Among } \\
\text { Elderly } \\
\text { People in } \\
\text { Baghdad, } \\
\text { Iraq, } 2017\end{array}$ & $4 . b$ & $\begin{array}{l}\text { to estimate } \\
\text { the } \\
\text { prevalence } \\
\text { and } \\
\text { determinant } \\
\text { s of mental } \\
\text { disorders of } \\
\text { elderly } \\
\text { living in } \\
\text { nursing } \\
\text { homes } \\
\text { (NHS) and } \\
\text { the elderly } \\
\text { who live } \\
\text { with their } \\
\text { families } \\
\text { (WF) in } \\
\text { Baghdad, } \\
\text { Iraq }\end{array}$ & $\begin{array}{l}\text { Design } \\
\text { research } \\
\text { using } \\
\text { comparativ } \\
\text { e cross- } \\
\text { sectional } \\
\text { study }\end{array}$ & $\mathrm{N}=362$ & $\begin{array}{l}\text { Geriatric } \\
\text { Depression } \\
\text { Scale } \\
\text { questionnaire }\end{array}$ & $\begin{array}{l}\text { Using SPSS } \\
21 \text { using chi } \\
\text { square and } \\
\text { multivariate } \\
\text { logistic } \\
\text { regression } \\
\text { followed by } \\
\text { binear }\end{array}$ & $\begin{array}{l}\text { The result } \\
\text { showed that the } \\
\text { elderly living in } \\
\text { nursing homes } \\
2 X \text { higher } \\
\text { prevalence of } \\
\text { depression than } \\
\text { with the elderly } \\
\text { at home with } \\
\text { family }\end{array}$ \\
\hline $\begin{array}{l}\text { Wroblews } \\
\text { ka, et al } \\
(2019)\end{array}$ & $\begin{array}{l}\text { Pain and } \\
\text { symptoms } \\
\text { of } \\
\text { depression: } \\
\text { internation } \\
\text { al } \\
\text { comparative } \\
\text { study on } \\
\text { selected } \\
\text { factors } \\
\text { affecting the } \\
\text { quality of } \\
\text { life } \\
\text { of elderly } \\
\text { people } \\
\text { residing in } \\
\text { institutions } \\
\text { in } \\
\text { europe }\end{array}$ & 3.c & $\begin{array}{l}\text { To perform } \\
\text { a } \\
\text { comparativ } \\
\text { e analysis of } \\
\text { the } \\
\text { symptoms } \\
\text { of pain and } \\
\text { depression } \\
\text { in elderly } \\
\text { living in } \\
\text { nursing } \\
\text { homes in } \\
\text { France, } \\
\text { Germany, } \\
\text { and Poland }\end{array}$ & $\begin{array}{l}\text { Cohort } \\
\text { study } \\
\text { design }\end{array}$ & $\begin{array}{l}\mathrm{N}=570, \\
\text { and } 190 \\
\text { elderly } \\
\text { women } \\
\text { from each } \\
\text { country }\end{array}$ & $\begin{array}{l}\text { Intervention } \\
\text { given the } \\
\text { Beck } \\
\text { Depression } \\
\text { Inventory } \\
\text { questionnaire } \\
\text { and scale } \\
\text { behavior of } \\
\text { elderly } \\
\text { DOLOPLUS }\end{array}$ & $\begin{array}{l}\text { Data were } \\
\text { analyzed } \\
\text { using } \\
\text { statistical } \\
\text { tests }\end{array}$ & $\begin{array}{l}\text { There is no } \\
\text { significant } \\
\text { difference, both } \\
\text { in the } \\
\text { prevalence of } \\
\text { pain and } \\
\text { symptoms of } \\
\text { depression or } \\
\text { in the average } \\
\text { level of quality } \\
\text { of life of elderly } \\
\text { in three } \\
\text { European } \\
\text { countries } \\
\text { The decline in } \\
\text { the quality of } \\
\text { life for their } \\
\text { various } \\
\text { complaints } \\
\text { elderly }\end{array}$ \\
\hline $\begin{array}{l}\text { Joanna } \\
\text { Kowalska, } \\
\text { et al (2019) }\end{array}$ & $\begin{array}{l}\text { Analysis of } \\
\text { the degree } \\
\text { of } \\
\text { acceptance } \\
\text { of illness } \\
\text { among } \\
\text { older adults } \\
\text { living in a } \\
\text { nursing } \\
\text { home } \\
\text { undergoing } \\
\text { rehabilitatio } \\
n-\text { an } \\
\text { observationa } \\
\text { l study }\end{array}$ & 3.e & $\begin{array}{l}\text { To assess } \\
\text { the } \\
\text { acceptance } \\
\text { of the } \\
\text { disease and } \\
\text { related } \\
\text { factors (data } \\
\text { socio- } \\
\text { demographi } \\
\text { c, } \\
\text { cognitive } \\
\text { status, } \\
\text { depressive } \\
\text { symptoms } \\
\text { and } \\
\text { functional } \\
\text { status) } \\
\text { among } \\
\text { patients }\end{array}$ & $\begin{array}{l}\text { Observatio } \\
\text { nal studies } \\
\text { involving } \\
\text { interventio } \\
\mathrm{ns \quad \text {and }} \\
\text { experiment } \\
\text { al structure }\end{array}$ & $\mathrm{N}=119$ & $\begin{array}{l}\text { Testing at } \\
\text { two points } \\
\text { using MMSE } \\
\text { questionnaire } \\
\mathrm{s} \text {, disease- } \\
\text { scale } \\
\text { acceptance, } \\
\text { GDS, and } \\
\text { Barthel Index }\end{array}$ & $\begin{array}{l}\text { Analysis of } \\
\text { data using } \\
\text { Shapiro } \\
\text { Wilk test } \\
\text { first and } \\
\text { then the } \\
\text { ANOVA } \\
\text { test }\end{array}$ & $\begin{array}{l}\text { Group studies } \\
\text { show relatively } \\
\text { low scores for } \\
\text { admission } \\
\text { diseases. } \\
\text { Results After } 3 \\
\text { months: Group } \\
\text { studies show } \\
\text { relatively low } \\
\text { scores for } \\
\text { admission } \\
\text { diseases. After } \\
3 \text { months } \\
\text { rehabilitation, } \\
\text { the disease has } \\
\text { a significant } \\
\text { acceptance } \\
\text { cantly } \\
\text { improved, but }\end{array}$ \\
\hline
\end{tabular}




\begin{tabular}{|l|l|l|l|l|l|l|l|}
\hline & & $\begin{array}{l}\text { living in } \\
\text { nursing } \\
\text { homes and } \\
\text { are being } \\
\text { rehab }\end{array}$ & & & & & $\begin{array}{l}\text { still remained at } \\
\text { a low level }\end{array}$ \\
\hline
\end{tabular}

\section{RESULTS AND DISCUSSION}

Elderly is a period in which a decline in various degenerative function, whether physical, psychological, and social. All men will feel the same way, both men and women. It is characterized by a decrease in visual function, hearing, tasting, cognitive, psychomotor, psychosocial even, until the properties and behavior like going back to childhood. Because when the elderly will experience a lot of sense of loss, such as loss of a spouse (husband or wife), children, other relatives, colleagues, your closest friends, occupation, position, finances, loneliness, happiness, and many more. This of course requires more attention from the family to accompany the elderly in these times.

But many among the elderly families who forget even neglect them. When a person is elderly transplant, the nature and behavior will be difficult to control, sometimes act without restraint until the unruly family. Things like this sometimes makes the family feel that the elderly will be very troublesome. Many of the families are less of a concern as a result of works, so rarely communicate with the elderly, less affectionate, assume indifferent, never again joking laughter with the elderly and even many of the families who entrust the elderly in nursing homes.

Therefore, the elderly will feel outcast of the family, not to be noticed, to feel useless, unhappy, lack of affection, loneliness to depression. Depression has some negative impact and can be a chronic problem. The impact of general common is the inability of the elderly in care of himself as well as the depression that leads to suicide. Another impact of depression can be physical disorders, such as insomnia, pain triggers hypertension, as well as behavioral disorders such as withdrawing from the social environment. So that is where the role of the family will be very necessary. Their full family support to reduce the level of depression elderly, especially elderly people living in nursing homes. However, depression in the elderly is not only happening in Nursing homes, but also in the family environment as well as in the general hospital when experiencing pain or get a physical illness.

Families are people nearby who can provide warmth and affection among fellow members of the family, including the elderly. Support their families and better attention to increase the health of the elderly, because they felt it would be quiet, happy, cared for, and no indifference. But if the lack of support from family, TLC is less, then the elderly will feel neglected, useless, and even depression.

According to Panju Pilenia, et al (2017), depression is a disorder with discrete feelings reduced vigor, a sense of low self-esteem, blaming yourself, sleep disorders, and eating patterns. In the depression and the symptoms of psychological and somatic 
symptoms. Symptoms of psychology, ie be quiet, sadness, pessimism, despair, desire to work and hang out less, can not make decisions, it is easy to forget and raised thoughts of suicide. Somatic symptoms, the patient did not look happy, tired, not excited, apathy, speech and the motoric was slowly, there are anorexia, insomnia, and constipation.

In the elderly who do research based on the testimony of the family are psychological and somatic symptoms, such as being quiet, sadness, hopelessness, decreased appetite, less sociable, unable to make decisions even raised the minds of suicide (in depression). Seeing the existing symptoms in the elderly, and also based on information from the family, the elderly as respondents suffer from major depression, indicated by a set of symptoms of both depression and light that accompanies everyday until some time, namely affective symptoms such as mental distress, sadness, crying, it occurred suicide and cognitive symptoms, such as not being able to take a decision. This is in accordance with criteria of Standard Diagnostic and Statistic Manual of Mental Disorder (DMS-IV) of the American Psychiatric Association,

Efforts to prevent and to treat the elderly with severe depression can be done with social support, care and treatment. Treatment efforts aimed at addressing natural disturbances feelings will have a negative impact. Such efforts, for example by forming coral Werdha and provide psychological therapy like cognitive exercises that can be carried out routinely in the elderly IHC performed on a scheduled basis. Treatment needs to be done in elderly depressed due to a physical disorder treatment is symptomatic, supportive according to the complaints and problems, while for the elderly who are already suffering from major depressive disorder can not eat, drink and has an intention to do suicide was conducted to get Electro Convulsi Therapy (ECT) in hospital type A or psychiatric hospital (Kwok Sylvia, dkk 2011; Timmerby, dkk 2016).

Sometimes symptoms of depression in the elderly is not visible, because the doctor thinks that it is a natural thing in the elderly. But with the aberrant behavior it would appear that the depressed elderly. Thus requiring more intensive care. Family roles are needed, but there are still many families who do not understand it. Thus the need exerts a greater knowledge through family psychoeducation therapy.

This therapy can be applied not only schizophrenia, but the psychosocial problems including major depression in the elderly, both physical and psychological problems. This therapy aims to improve the understanding and skills of families and family preparedness in the face of the elderly who experience depression. Families can unload their feelings when treating the elderly and why to decide to bring their families to the elderly Elderly homes. So the family is expected to have a positive coping for the elderly and the existing load.

The family psychoeducation therapy can improve cognitive abilities as an element in therapy to improve family knowledge about the disease, teach techniques that can help families to know the symptoms of deviant behavior, as well as increased 
support for the family members themselves. The aim of this educational program is to improve the achievement of family knowledge about the disease, teaches families how teaching techniques to help their families in an effort to protect his family by knowing the symptoms of behavioral and supportive family strength (Katsuki et al, 2018; Kowalska, et al 2019).

Psychoeducational program activity for families according to Tursi, MF, et al (2013), which can enhance the ability of didactic elements that are didactic component provides information about mental illness and mental health system in this paper is more focused on the elderly with depression. Cognitive ability to increase the family was able to know the causes, signs symptoms of depression as a result families are able to care for the elderly. The most important of family psychoeducation program is to meet the family based on the needs and the family gave kesempatan to ask questions, exchange views and to socialize with other members and mental health professionals. Research proves very effective family psychoeducation given to the family (Tursi, Baes, Camacho, Tofoli, and Juruena, 2013).

The increasing of psychomotor ability in the intervention was possible because the family psychoeducation therapies related to their practice skills component consisting of communication, conflict solving exercises, assertiveness training, exercise and behavioral overcome stress. Increased psychomotor ability is probably related to the learning theories that explain that one learns not only from direct experience, but of imitation, imitation (modeling). The behavior is the result of cognitive and environmental factors means that someone is able to have certain skills when there is a positive braid and stimulus were observed and the characteristics of a person. Psychomotor abilities in caring for the client (in this case is the elderly) is aimed at the family's ability to always give praise and appreciation, seeks to support the treatment with the client treatment to health care and frequent visits to the elderly if it is placed at the center Werdha. Another possibility is reinforced by the magnitude porposi age and education level of families in this group.

In accordance opinions of Rodrigues et al. (2014) that psychoeducation is the approach taken to provide information to the families who suffered distress, educate them to improve skills, to be able to understand and improve coping due to a mental disorder dpat cause problems in the family.

The study is in line also by Biswajit et al. (2017) stated an increase of $33 \%$ in the group given therapy clients schizophrenia after family psychoeducation, because the family psychoeducation provides for an increased positive relationship between family members, increase stability keluraga, stess management family, family motor skills through role play.

As research conducted by Timmerby (2016) states that an increase in significant differences in the ability of the family aspect for the implementation of family psychoeducation running intensive sessions of one to four sessions and each participant 
to follow from beginning to end. Results of the study according to the theory presented by Goldenberg (2014) that the Family Psycoeducation is a therapy that is used to provide information on the ability of families experiencing distress, educate them to improve the ability to be able to understand what was and have coping due to a mental disorder which cause problems in relationships family. According to Jennifer et al. (2005) and Baumul et al. (2006) Family psychoeducation therapy is very effective because it provides information on preventive and promotive, coping skills, cognitive behavior and skills for families.

Other research also revealed by Sidhomera Shinji, et al (2012) which states that of 57 pairs of family members of patients assigned to intervention and the other in the control group refused to undergo a baseline assessment, and one patient in the control group died due to physical illness), resulting in 24 and 30 patients were evaluable for the intervention and control group respectively.

Basically, characteristics of the two groups showed that the group is very similar for all variables. All 54 patients with depression continue treatment for 9 monthsand evaluated for further action. One patient in each group stopped taking the drug at that time that recurrences before the treatment is completed. Family very significant role in the treatment. Thus, families with elderly people who are depressed may be granted family psycho-education therapy. So as to improve knowledge of the family and improve the coping mechanisms of elderly and family.

\section{CONCLUSION}

Family support is needed in elderly depressed, not only in nursing homes but in all living quarters. Both within the family and the elderly who are in the hospital because of physical illness. Their attention and affection toward the elderly can lower levels of depression and bring happiness to the elderly, self-confidence, and ability to move. Family psychoeducation therapy can improve cognitive and psychomotor abilities significantly. So it can be used to improve the elderly and families coping itself. This therapy is not only used for people with schizophrenia, but also the patient's psychosocial, including depression in the elderly.

\section{REFERENCES}

1. Alvarenga, M. R. M., de Campos Oliveira, M. A., Faccenda, O., Cerchiari, E. A. N., \& Amendola, F. (2010). Sintomas depressivos em idosos assistidos pela estratégia saúde da família. Cogitare Enfermagem, 15(2).

2. Alvidrez, J., Areán, P. A., \& Stewart, A. L. (2005). Psychoeducation to increase psychotherapy entry for older African Americans. The American Journal of Geriatric Psychiatry, 13(7), 554-561.

3. Aswanira, N., Rumentalia, R., \& Vausta, V. (2015). Efek Life Review Therapy terhadap Depresi pada Lansia. Jurnal Keperawatan Indonesia, 18(3), 139-142. 
4. Bäuml, J., Froböse, T., Kraemer, S., Rentrop, M., \& Pitschel-Walz, G. (2006). Psychoeducation: a basic psychotherapeutic intervention for patients with schizophrenia and their families. Schizophrenia bulletin, 32(suppl_1), S1-S9.

5. Bishwajit, G., O'Leary, D. P., Ghosh, S., Yaya, S., Shangfeng, T., \& Feng, Z. (2017). Physical inactivity and self-reported depression among middle-and older-aged population in South Asia: World health survey. BMC geriatrics, 17(1), 100.

6. Brady, P., Kangas, M., \& McGill, K. (2017). "Family matters": a systematic review of the evidence for family psychoeducation for major depressive disorder. Journal of marital and family therapy, 43(2), 245-263.

7. Rodriguez, G. (2014). A Psychoeducational Support Group for Latino Older Adults Experiencing Symptoms of Depression: A Grant Proposal. California State University, Long Beach.

8. Hao, G., Bishwajit, G., Tang, S., Nie, C., Ji, L., \& Huang, R. (2017). Social participation and perceived depression among elderly population in South Africa. Clinical Interventions in Aging, 12, 971.

9. Ibrahim, A. A., Ai-Lami, F., Al-Rudainy, R., \& Khader, Y. S. (2019). Mental disorders among elderly people in Baghdad, Iraq, 2017. INQUIRY: The Journal of Health Care Organization, Provision, and Financing, 56, 0046958019845960.

10. Jones, R. B., Thapar, A., Stone, Z., Thapar, A., Jones, I., Smith, D., \& Simpson, S. (2018). Psychoeducational interventions in adolescent depression: a systematic review. Patient education and counseling, 101(5), 804-816.

11. Katsuki, F., Takeuchi, H., Inagaki, T., Maeda, T., Kubota, Y., Shiraishi, N., ... \& Akechi, T. (2018). Brief multifamily Psychoeducation for family members of patients with chronic major depression: a randomized controlled trial. BMC psychiatry, 18(1), 207.

12. Kim, M., \& Park, J. M. (2017). Factors affecting cognitive function according to gender in community-dwelling elderly individuals. Epidemiology and Health, 39.

13. Kowalska, J., Mazurek, J., \& Rymaszewska, J. (2019). Analysis of the degree of acceptance of illness among older adults living in a nursing home undergoing rehabilitation-an observational study. Clinical interventions in aging, 14, 925.

14. Kwok, S. Y., Yeung, D. Y., \& Chung, A. (2011). The moderating role of perceived social support on the relationship between physical functional impairment and depressive symptoms among Chinese nursing home elderly in Hong Kong. TheScientificWorldJOURNAL, 11.

15. Melin, E. O., Svensson, R., \& Thulesius, H. O. (2018). Psychoeducation against depression, anxiety, alexithymia and fibromyalgia: a pilot study in primary care for patients on sick leave. Scandinavian journal of primary health care, 36(2), 123-133.

16. Metcalfe, I. M., Padilla, I. L., Lozano, M. D. R., Gómez, C. C., Sobrado, M. M., \& Calvente, M. D. M. G. (2019). Desigualdades de género en los impactos del cuidado 
informal de mayores dependientes en Gipuzkoa: Estudio CUIDAR-SE. Rev Esp Salud Pública, 93(28), e13.

17. Mirzaei, M., Sahaf, R., Mirzaei, S., Sepahvand, E., Pakdel, A., \& Shemshadi, H. (2015). Depression and its associated factors in elderly nursing home residents: A screening study in Khorramabad. Iranian Journal of Ageing, 10(1), 54-61.

18. Na, L., \& Streim, J. E. (2017). Psychosocial well-being associated with activity of daily living stages among community-dwelling older adults. Gerontology and Geriatric Medicine, 3, 2333721417700011.

19. Nowak-Kapusta, Z., Durmała, J., Cieślik, A., \& Bąk, E. (2018). Functional efficiency evaluation for the elderly staying in nursing homes. Journal of Education, Health and Sport, 8(6), 80-92.

20. Piadehkouhsar, M., Ahmadi, F., Khoshknab, M. F., \& Rasekhi, A. A. (2019). The effect of orientation program based on activities of daily living on depression, anxiety, and stress in the elderly. International Journal of Community Based Nursing and Midwifery, 7(3), 170.

21. Rosney, D. M., Noe, M. F., \& Horvath, P. J. (2017). Powerful Tools for Caregivers, a group psychoeducational skill-building intervention for family caregivers. Journal of caring sciences, 6(3), 187.

22. Sendra-Gutiérrez, J. M., Asensio-Moreno, I., \& Vargas-Aragón, M. L. (2017). Characteristics and factors associated with depression in the elderly in Spain from a gender perspective. Actas Esp Psiquiatr, 45(5), 185-200.

23. Sharifi, F., Mirarefin, M., Alizadeh-Khoei, M., Nazari, N., Najafi, B., Fakhrzadeh, H., ... \& Mehrdad, N. (2018). Psychometric properties of the Persian version of the nutritional form for the elderly (NUFFE) in nursing home residents. Medical journal of the Islamic Republic of Iran, 32, 105.

24. Shimodera, S., Furukawa, T. A., Mino, Y., Shimazu, K., Nishida, A., \& Inoue, S. (2012). Cost-effectiveness of family psychoeducation to prevent relapse in major depression: results from a randomized controlled trial. BMC psychiatry, 12(1), 40.

25. Timmerby, N., Austin, S. F., Ussing, K., Bech, P., \& Csillag, C. (2016). Family psychoeducation for major depressive disorder-study protocol for a randomized controlled trial. Trials, 17(1), 1-10.

26. Tursi, M. F. D. S., Baes, C. V. W., Camacho, F. R. D. B., Tofoli, S. M. D. C., \& Juruena, M. F. (2013). Effectiveness of psychoeducation for depression: a systematic review. Australian \& New Zealand Journal of Psychiatry, 47(11), 1019-1031.

27. Wróblewska, I., Talarska, D., Wróblewska, Z., Susło, R., \& Drobnik, J. (2019). Pain and symptoms of depression: international comparative study on selected factors affecting the quality of life of elderly people residing in institutions in Europe. BMC geriatrics, 19(1), 147. 